\title{
Assessing the Ethicality of Promoting the Current Egyptian Regime by Some Egyptian Channels: The Complete Cure Device as a Case Study
}

\section{Yosra Jarrar, Girne American University, TRNC}

\begin{abstract}
This descriptive analytical study aims to assess the ethicality of the coverage of the release of the Egyptian military-invented device, the Complete Cure Device CCD, by some privatelyowned Egyptian channels. The TARES test is used as a rubric to assess how ethical the coverage is. Critical discourse analysis is used as a framework. Analysis has shown that the channels lend themselves to hope propaganda to spread the ideology of democratizing the military rule on the one hand, and to maximize the potential electoral benefits on the other. It also shows how the journalistic practices of the media do not meet the mark for the TARES test ethical questions.
\end{abstract}

Keywords; Complete Cure Device, TARES test, Democratizing Military Rule, Hope Propaganda 


\section{Introduction}

Throughout history the manufacture of consent as a propaganda model has tended to filter and frame the issue of the day in a way that strongly favors particular interests; usually those of a government (Herman \& Chomsky, 1988). For Althusser, mass media as a social agency functions as a repressive state apparatus that inculcates the value of the state not through coercion but by engineering consent. Moreover, and as can be seen in today's world, the ideological role that the mass media plays in the establishment of legitimacy is essential for political stability. However, the constant and recurring question as to what governs the professional and ethical practices of journalists as subjects through the operation of ethical codes is controversial.

In her book "Ethics and Journalism", Sanders (2003) provides a comprehensive overview of the main theories of ethics in relation to media, from Plato, Socrates, Kant, Mill to more modern approaches of moral philosophy. She also sheds light on conflicting ethical traditions and suggests that the mere fact that two or more moral traditions differ in their priorities shows that they must share some common features. This can also be related to Cooper's (1966:14) concluding notes in his paper: Preposition to Moral Judgments, where he states that:

By examining the morally but normative principles which enables us to reject certain moral judgments, we can come to a better understanding of the role reason can play as a preliminary to moral decision and the variety of methods by which we can show a moral judgment to be untenable. There are more ways of killing a cat than drowning it in butter.(Cooper,1966, p.14)

It was Feb 112011 when the Egyptian army won the heart of the public by choosing them over Husni Mubarak. However, it did not take the protesters long to demand an end to the military rule, since Egypt was ruled by graduates of the military establishment from 1952 to 2012. Mohammad Morsi was then elected as Egypt's first freely-elected and civilian president. After one year and on July 3, Morsi was ousted by the army who chose the people over the president for the second time. Ironically, the opponents of the military rule became proponents of the same rule after the overthrown of Morsi. 
In his article: "Is Egypt heading to "Ikhanization", "Wafdanization" or "Militarization"? Saleh (2013) explains that the conflict in Egypt can be seen as an ideological struggle that is directly related to the reformation of Egypt's identity and policies. He states that there are two main ideologically opposed camps; the Islamic and Secular, while there are three powerful actors that define the political structure in Egypt: the army, the Islamic trend, and the secular trend. This can be related to Van Dijk's (1996:7): definition of ideologies:

Ideologies are conceived as basic systems of shared social representations that may control more specific group beliefs (knowledge, attitude), and influence models via the instantiation of such beliefs in concrete models of situations and experiences. Ideologies themselves have to be inferred from more directly observable structures, cognition, interaction and society.(Van Dijk, 1996, p7)

Moreover, other definitions view ideologies as representations of issues in the world which aim to create, keep or even change relations of power and domination (Fairclough, 2003). According to Wolfsfeld (1997) an ideological statement may go further than its aim of changing attitudes to the extent of calling for action.

Consequently, and as Saleh (2013) suggests, the reformation of a secular Egypt differs from that of an Islamist one, and an Egypt with a grand coalition government that involves all parties differs from an Egypt that is governed by the military.So the reformation of the country is expected to be affected by many factors, chief among these is the media.

After the overthrown of Morsi, General Abdel Fattah el-Sisi, the commander-in-chief of the armed force of that time and who was promoted to the rank of field marshal in January, was seen as a national symbol, a hero who put the welfare of the country in front of his career.Since then, the national Egyptian media has, on the one hand, continued on urging elSisi, to run for Egypt presidency, which he did in Mach 2014, and on stressing the need for a president with a military background to be able to control the country. On the other hand, the media hasplayed a major role spreading the "Sisi fever" by hosting or reporting people who support him in their own ways starting from designing Sisi-shirts and posters to making chocolates with his portraits and even creating new "eye-catching" jewelry lines inspired by him. The media's celebration of el-Sisi and elevating him to celebrity status on any platform continued when some national Egyptian channels, mentioned below, broadcasted a press 
conference of the Egyptian armed forces, announcing a miraculous army-made device, the Complete Cure Device, which cures Aids, Hepatitis and other viruses.

This paper questions the extent to which the coverage of some privately-controlled Egyptian channels is shaped by a particular ideological stance and the degree to which they produce government propaganda. It examines how truthful, authentic, respectful, equitable and social responsible the national Egyptian channels' converge and celebration of the release of the "invention" is.

\section{Literature Review}

\section{Propaganda and Ethics}

Ellul (1981) states that there is no way to make an ethical judgment on propaganda since it follows the principles of efficacy. However, he claims that although propaganda does not obey ethics, it has to build an ethical content and come to have an artificial ideological moral presentation in order to appeal to both the propagandee and propagandist. Consequently, propaganda can be seen as "an end integrated into its means" (p.160). Ellul suggests that propaganda aims at hiding reality within an ideological discourse that justifies it by the mere fact of being "moral", auto-justification, and this show how weak the most evident facts can be against the morality acquired by propaganda. He continues his claim by stating that propaganda has the power to eliminate the other, totalitarianism, and erase the past to create a new morality that serves the current desired goals; and this represents Ellul's third axis of ethical reflection on propaganda as he does not believe in the morality of instantaneousness.

Ellul bases his claim that propaganda "is the conferrer of morality while at the same time being essentially amoral" (p.163) on the three above explained critical themes: autojustification, totalitarianism, and instantaneousness of morality. This was the starting point for Marlin's (2005) critique of Ellul's ethics of propaganda where he questions Ellul's "contradictory" deception of the nature of propaganda. For him, while Ellul considers propaganda as an antiethical practice, he accepts that it is amoral. Marlin's critical assessment deals with Ellul's subjection of propaganda in totality. He believes that through this subjection propaganda constitutes its own ethical sphere. That is to say, as propaganda contains its own moral system, it becomes ideologues and immune to critique and other's interferences. 
Cunningham (1992) claims that propaganda cannot be seen as an ethically neutral enterprise. In his threefold critique of the neutralist account, he argues that an examination of the propagandist's pattern of truth-use shows how propaganda undermines the values of truthfulness. Therefore, it can be best described as a kind of pseudo-communication. He also discusses the ethical considerations of both the sender and receiver; the propagandist is responsible for what he propagates, while the propagandee is epistemically responsible for whom he chooses to trust and what he chooses to believe. Finally, he refers to Hegel's principle of transition to prove the immorality of propaganda. He shows how a change in quantity can result in a new quality (e.g. justice, social well-being, accountability) in the moral sphere where the right can become wrong and vice versa.

As shown above the question of whether propaganda is moral, immoral or amoral is a controversial one in literature. Different ethical positions differ in their definition and perception of the inherent unethicality or the neutrality counter-thesis of propaganda. The ethical challenge, however, is not to favor or legitimate one criticism over the other, but is , as suggested by Capurro and Britiz (2002), to promote ethical critical thinking in different contexts in order to "preserve ethical sensitivity" (p.34).

In his article "The Ethics of Propaganda and the Propaganda of Ethics", Black (2001) proposes that in today's media the crucial question is not weather our societies and social institutions engage in propaganda, it is rather a question of how they do so. He suggests six characteristics of media including its heavy or undue reliance on spokespersons of authority rather than on empirical evidence, a usage of unverified abstract language, a fixed view through which people, institutions and situations are seen in term of binary opposites, a neglect of the multiple causality of events, an overemphasis or a neglect of certain aspects of the past, present or future and an exaggerated coverage of conflict. He assumes that considering propaganda in "less value-laden" terms enables us to fully interpret and judge the key issue at stake.

Black also provides insights into the nature of "new propaganda" by showing how modern governments and modern media corporate. According to Rich (2006) (as cited in Black, 2001) the George W. Bush administration spent more than 1.6 billion between 2003 and early 2005 on domestic and international propaganda. The government Accounting Office report 
shows that the money was spent on advertising and public relations campaigns in addition to 131 media organizations and 8 individual members of the media (Rich, 2006). An example is that the Defense Department and the Pentagon's Psychological Operation Unit paid the Lincoln Group, a DC public relation firm, more than 130 million to deliver propaganda. In another campaign, and at the international level, Iraqi journalists were paid to publish public news stories written by American military personnel in Iraqi newspapers. Donald Rumsfeld, Secretary of Defense at that time, described the fake pro-American news stories as a "nontraditional means" of providing accurate information to the Iraqi public. At the national level, on the hand, the New York Times reported that hundreds of fake news programs were produced and distributed by at least 20 federal agencies and that the local television stations did not identify the sources of the reports. The section below shows how the media utilize certain election propaganda techniques to enhance certain ideologies.

\section{Propagandain Elections}

In their book "The Media and Elections: A Handbook and Comparative Study", Lange and Ward (2004) present a collection of essays that provide a comparative overview of the political systems, media structure and ownership, and the body of law and regulations that governs the media coverage of elections in seven countries: Italy, USA, Germany, South Africa, France, Russia, and the United Kingdom. Lange (2004) states that the objective coverage of media is sought to guarantee free and fair elections since:

Biased media will lead to judgments and actions that are not self determined by the otherwise sovereign people. Media coverage has become such an important element of the run-up to elections and for elections themselves that, if the media coverage in the press and on television is not free and fair, the results may be prejudiced to an extent that the elections as a whole, even if the formal process of voting has been organized correctly, may be judged not to have been free and fair.(Lange, 2004, p.226)

Towards the end of the book Lange (2004) also provides some reflections and recommendations since none of the studied countries has a perfect model for organizing and monitoring the media coverage of elections. Although he emphasizes the universality of the norms of journalistic coverage of elections, he explains that since different countries have different histories, culture, and experiences, special emphasis should be laid on the socio- 
cultural or socio-political context of each country in order to be able to evaluate the media coverage of elections. He considers the provided guidelines as both a checklist that is derived from the democratic experience of many countries, as well as a positive benchmark for the future of a civil society.

Kellner (2005) criticizes the failure of the American mainstream media to highlight the "systematic lies" of the 2004 Bush-Cheney campaign. He presumes that the US democracy has been undermined by three factors: the corporate governance of mass media which is directed toward conservatism and profit, deterioration in access to information and a tendency to portray politics as a form of entertainment, and the rise of right-wing Republican media propaganda and attack apparatus that spread the agenda of conservatives through lies and deception. He provides many examples to show how the Republican propagandists support the Bush-Cheney administration and wage a war against whoever criticizes them. He blames the "cowardly" mainstream media for the decline in investigative reporting and the failure to report the distortions and lies in Bush Campaign.

He stresses the need for democratizing the media and producing alternative media in order to improve the current status. For him, this requires criticism of the highly ideological corporate media, re-regulation of the media practices, revival of investigative reporting, public television and radio, and a free democratic usage of the internet to revive the public sphere.

Willems (2012) proposes a symbiotic relationship between the media and politicians, in the African context, that aims to promote and legitimize certain candidates. This is demonstrated by an example of the coverage of two Zimbabwean election rallies by two ideologically opposed Zimbabwean newspapers. Both newspapers provided conflicting polls on the popularity of the two political parties in order to legitimize the preferred party of each. She also provides examples of allegations of deliberate bias in the coverage of the state-controlled Zimbabwe broadcasting Corporation in favor of the ruling party with whom they share a joint agenda. In her article, Willems shows that the study of media and elections involves more than dealing with elections as an aspect of the citizen participation in the legislative process by voting or even emerging as candidates. What is more important is understanding the local context in which elections take place to highlight the symbiotic relationship between politicians and media in that particular context. The following section deals with different 
justification models for doing ethics. As propaganda can be seen as a systematic attempt to manage perception, such systematic frameworks may be implemented to analyze it.

\section{JustificationModels}

Black and Roberts (2011) propose that while ethical codes may be beneficial, studies on moral philosophy and normative ethics requires the implementation of justification models, "ethics formula or decision-making matrices that we flow to their logical conclusion" (p.49), which provide systematic frameworks for thinking ethically. They point out that application of these models is not intended to force choice; it is rather intended to help us to make and ethically justify a decision. They present five models, some of them are more appropriate to one field of communication that to others, from literature before providing their own model for doing ethics.

The members of Rotary International which is a global service organization are supposed to adhere to the Rotary-Four Way test which consists of the following four questions:

Is it the truth?

Is it fair to all concerned?

Will it build good will and better friendship?

Will it be beneficial for all concerned?

Bok's Test of Veracity is a three-stage justification model that requires a satisfactory answer to each of the following questions:

Are there alternative actions that will resolve the difficulty without lying?

What are moral reasons to excuse the lie, and what reasons can be raised as counterarguments?

As a test of the first two steps, what might a public of reasonable persons say about such lies? Black and Roberts (2011) explain that even if we manage to provide satisfactory answers to the first two stages, lying cannot be "justified" if it does not "pass the test of publicity".

The Society of Professional Journalist Model is based on four principles:

Seek truth and report it

Minimize harm 
Act independently

Be accountable

Ralph Potter's justification model, the Potter Box, of moral reasoning is a rational and systematic approach that enables a person to:

Define the ethical situation objectively and in detail

Identify values that relate to the situation

Inject moral philosophy as a justification for a decision

Choose to whom one is ultimately loyal

They introduce their own model for doing ethics by asking the "5 Ws And H" which are:

What's your problem?

Why not follow the rules?

Who wins, who loses?

What's it worth?

Who is whispering in your ear?

How is your decision going to look?

The TARES test is also presented as a philosophically complex model for doing ethics. Baker and Martinson (2001) present the five-principle test that defines the morality based end, establishes the ethical boundaries of ethical persuasion and provides guiding principles for professional persuasion. The five principles are: Truthfulness of the message, Authenticity of the persuader, Respect for the persuadee, Equity of the persuasive appeal and Social responsibility for the common good. Each principle examines a particular aspect of the "persuasive act" from the point of view of the sender of the message. The test consists of reflection and application tables that include check-lists which reflect the core of each principle. They suggest that the questions in the tables can be modified in different persuasive contexts to highlight the ethics of the persuasive practices in each. They also propose that the test is of prima facie duties. However, when the duties conflict, the context should be taken into consideration to decide which principle has the greatest moral claim in that particular context. 
Waters and Melton (2006) explains that the test is designed to provide the persuader with an ethical framework to check the ethicality of his persuasive mediated message. They examine whether the test can be used an analytical tool to assess the ethicality of already mediated communication using the World Vision reports "special reports" as the artifact subject for their analytic paper. They conclude that only through dialogue with the creator of the persuasive message, a better understanding of the total ethical picture can be guaranteed. The TARES test is used in this study as a rubric to examine the ethicality of the national Egyptian channels' converges of the invention as explained below.

\section{Methodology}

\section{Purpose of the study}

The purpose of this descriptive analytical study is to examine how truthful, authentic, respectful, equitable and social responsible some privately-controlled Egyptian channels' converge and celebration of the release of the "Complete Cure Device" is.

\section{Questions of the study}

The study attempts to answer the following questions:

What propaganda techniques are used in the pre-election campaign?

What ideologies are observed and practiced on the privately-controlled Egyptian channels under study?

Does the coverage of the channels under study adhere to the five ethical principles of the TARES test?

\section{Data Collection}

The data of this study consists of the Egyptian army's press conference to announce the invention (broadcasted by the National Egyptian TV among many other channels), news reports, and extract from talk shows aired by privately-controlled Egyptian channels and uploaded on YouTube. The channels include: Sada Al-Balad, ON TV, Al-Hayah, Al-Kahera Wal Nas, Al-Fareen and Al-Tahrir. ${ }^{1}$

\footnotetext{
${ }^{1}$ Sada Al-Balad TV was founded after the revolution in 2011. The channel is owned by Mohammed Abul-Enein of the Cleopatra Group.

ON TV was launched in 2009 by Egyptian billionaire Naguib Sawiris.
} 


\section{Data Analysis}

In this study the TARES test is used as a rubric to examine how truthful, authentic, respectful, equitable and social responsible the national Egyptian channels' converge of the invention is. Since the five parts of the test are morally interrelated, as can be seen from the overlapping questions in the reflection and application tables in the test, questions from the five parts are answered to check if the coverage adheres to the five principles. Different aspects are discussed using examples from the different programs. Every aspect may not be discussed in the light of all programs. Rather, it is discussed in terms of the most pertaining examples. The study also uses the critical discourse analysis as a framework. In analyzing the videos, the footsteps of critical discourse analysts (Van Dijk, 1988 and Flower, 1991) in their selection of some linguistic tools and devices in analyzing media texts are followed. Discursive strategies including naming strategies, quotation patterns and over-lexicalization are analyzed.

\section{Findings and Discussion}

\section{Hope Propaganda, Myth Making and Lack of a Duty of Care}

The following analysis shows the degree to which the Egyptian channels under study lend themselves to "dishonest" propaganda to spread the ideology of democratizing the military rule on the one hand, and to maximize the potential electoral benefits on the other. It also shows how the journalistic practices of the channels do not meet the mark for the TARES test ethical questions.

Before showing a report ("Egyptian Army", 2014) on the new "miraculous" device, Sada AlBalad's presenter refers to the many reactions to the televised press release on the invention of the Egyptian Military Engineering Department. She explains that the invented device, which has been secretly developed during the last twenty-two years, can eliminate Hepatitis

Alhayah TV was founded on July 1, 2013 and their website is under construction.

Al Kahera Wal Nas was founded on July 20, 2012 and owned by TN Holdings.

Al Tahrir TV was launched in February 2011. It was founded by: Ibrahim Eissa, Ahmed Abu-Haiba, and Mohamed Morad.

Al-Fareen TV was founded on Oct 25, 2008 and owned by Tawfiq Okasha. 
C virus within ten days, with no side effects and with $100 \%$ success rate. The way the presenter introduces the report seems to be intended to direct the audience into a predetermined direction of ideological content that the reporter, Mohammad Hafith, states clearly through the report. He praises the military through what Flower (1991:85) refers to as the process of over-lexicalization as can be seen in the following examples:

"We are now facing a medical miracle brought to you by the Egyptian military."

"Egypt has become the first country to produce a cure for these diseases."

"In 2010, the Egyptian military successfully invented a device that can identify a carrier of Hepatitis C in a crowd."

"Today using the same technology they have invented a treatment device."

"Despite all the difficult times Egypt is undergoing and the pressure on the army, the men of the military proved to the world that they are men who insist on serving the homeland with all their might."

"The Egyptian army continues to be a symbol of giving and sacrifice for the sake of their great people and the glory of this homeland."

The process of over-lexicalization can also be traced in the press conference at which General Taher Abdulla, the head of the army's engineering department, announced the invention as well as in General Abdel Atti’s press conference (“Egyptian Army Medical Research”, 2014). The primary focus of the conference is to parse the Egyptian army. A video shown in the conference and on the National Egyptian TV (among many other Egyptian channels including Al-Tahreer, Al-Fareen, Sada Al-Bald who celebrated the invention), shows General Abdel Atti assuring a patient that he was $100 \%$ cured from AIDS. The video also shows a portable device with an antenna that is claimed to remotely detect the virus using electromagnetic waves, Abdel- Atti gave credit to an early detection device invented by the military (C-Fast). After the detection of the virus, the Complete Cure Device is claimed to purify the patient's blood in a manner similar to a dialysis device as shown in the video.

In his press conference, Abdel Atti assures the audience that the AIDS has been defeated by the Egyptian Army as can be seen in the following examples of over-lexicalization:

"We defeated AIDS, and rest assures we defeated AIDS."

"And we will never import medicine, costing Egypt to treat even one Egyptian from AIDS, for even one penny, God willing, this is my hope." 
"I was offered \$2 billion to sell the device abroad. I asked them to announce that the device was invented by an Arab Muslim scientist. They asked me to forget these words and take the check."

"I ran a way to my country where the Egyptian Intelligence forces protected me."

"The main supporting role on this achievement is due to the armed forces "mens" and "mens" is the plural form of men, every man in the armed forces is "men" not only a man."

"And indeed I conquered AIDS with the blessing of my Lord, glory to Him, with a percentage of $100 \%$, and I conquered the C, and you will never find a patient suffering from the Hepatitis C virus after today, God willing."

"The AIDS crumbles and becomes as I say in parables: I take the AIDS from the patient and feed him on AIDS, I give it to him as Kofteh (a meat dish)"

"I take the disease and give it to him as nutrition, and this is the top of scientific miracles."

"I thank Marshall El-SiSi who cared for this research and was a whip, because he said an aphorism that still rings in my ears, he said that we are at the back"

"We cannot just walk like others, we need to jump, and this is the first jump, conquering the AIDS worldwide, conquering the AIDS worldwide, God willing."

"In addition, treating my people, my family, my country since we are the most affected worldwide with Hepatitis."

By examining the above extract from the report and press conference, an extensive and repetitive usage of lexical devices to construct a profile the armed forces men as heroes can be seen. Such dominant codes or textual conventions define the prevailing ideology that frames the text. Thus, they bring many questions on the motives behind this process of overlexicalization, as a propaganda tool, that seems to be intended to result in a "preferred reading" that guides, limits or controls its interpretations by the audience.

Abdel Atti tends to use rhetorical strategies to appeal to the audience's emotions and feelings through the evocation of personal pride and patriotism. He used the pronoun "We" to accomplish the sense of collectivism, to develop a bond between the audience and the military. He also touches on a raw nerve by repeating the phrase "God willing", as Muslims are most likely responsive to religious appeals. Abdel Atti refers to each member of the Egyptian Armed Forces as a group of men, using the word "rijaalaat"which is the plural of 
plural in Arabic, to show that each member who is attentive to his duties and loyal to his country makes a majority. He refers to Marshal El-Sisi as a "whip" in the metaphor: "He was a whip", to represent him as an inspirational person, marked by impressive wisdom. The metaphor eludes the influence of El-Sisi's aphorism to a cracking sound that keeps ringing in Abdel Atti's ears to remind him of his responsibilities. According to Van Dijk (1988), such interpersonal functions of discourse; naming and quoting patterns, are usually intended to provide the speaker with a sort of authenticity, objectivity and credibility.

Moreover, several doctors and members of the research team assure that the Complete Cure Device can cure some other viruses. In a live call-in show on ON TV, Dr. Sali Mostafa, a member of the research team, claims that the device cures AIDS, Hepatitis C, Psoriasis and it may be able to cure Swine flu in the near future("The Program, Season 3, Episode 4 ", 2014). On Al-HayahTV, Dr. Ihsan Hanfi also claims that the device can cure Diabetes, Psoriasis and even Cancer which are not caused by viruses in the first place ("The Program, Season 3, Episode 4", 2014).

This all happens at a critical timing in Egypt which has been undergoing tremendous changes in the last three years since Mubarak's overthrown in 2011. The announcement of the invention at this particular time helps legitimize and empower the presence of the military and coup regime in the upcoming presidential elections. It also helps envision a brighter future of the country in the presence of the armed forces men who devote themselves to the prosperity of their country and well-being of their fellow people. However, for many Egyptians the democratizing of military rule may signal the end of democracy and the return of the police state, military regime, and dictatorship.

By exploiting the cutting-edge technology, the military is seen as a savior who will cure the sick, insure the national security, revitalize the economy and continually strive to exalt the might and power of the country. This is evident by General Taher Abdullah's statement, to the Egyptian Daily Al-Ahram, that the device will not be exported in order to protect the army from the mafia of nations that control the pharmaceutical industry (Salim, 2014). Moreover, a report on CCTV Africa shows that the cure is going to be available to the Egyptian public in all military hospitals by June 30 but Egypt will delay exporting the technology to become a central hub for medical tourism in the world ("Egypt's Military 
Medics", 2014). This, on the one hand, casts doubt on the changing role of the army from a protector of national security into a political player that may have a main role in the upcoming presidential poll sand in ruling Egypt. It, on the other hand, raises the vital question of whether el-Sisi is the army's candidate and of whether his determination to run for presidency may jeopardize the army's integrity.

The invention is presented as a mythical device that promises health and wealth. Such discourses of governments' mythical scientific superiority, hope propaganda, and the manufacture and spread of awe-provoking ideologies can be traced through the history of colonialism and post colonialism (See Prakash, 1999, Mosco, 2004, Chakravartty \& Sarikakis, 2006). Unfortunately, utilizing such hope propaganda for strategic purposes is not new for the Egyptian people either. As Hammodeh (2014), of the New People Newspaper, points out in his article "Will the Kofta Invention Signal a New Naksa?" He recalls how General Abdel Nasser's regime depended heavily on hope propaganda in marketing the national policies. An example is what was published before the Palestanian Naksa Day (the Day of Setback) in Al-Alhram newspaper, under the Chief editor Mohamed Hassanein Heikal who was a major opponent of the ousted president Mohammad Morsi. On its front page headline we read:"Al Ra'aed" a new multi-stage missile appeared in the military parade yesterday "- and beneath it:" The new missile has a range of 1000 kilometers and can penetrate the Earth's gravitational field into outer space "and under the news also:"7 new weapons appeared for the first time in the big military parade ". We also read a headline in" Al-Ahram ":" Abdel-Hakim Amer announced in his speech: The fleet was able to make a submarine "Jeep" that goes down into the sea in two weeks "- and underneath it the news: "A huge scientific and military triumph of the United Arab Republic: An experiment was conducted of the first fighter aircraft designed and manufactured in the United Arab Republic (ie, Egypt) and the experiment succeeded," and "the new aircraft exceeds the speed of sound twice-The big secret that Cairo kept until it materialized ". Hammodeh explains that such was the news at the time, and yet we still have not seen those powerful inventions nor did they see the light anywhere else in the global space.

After all, the media has dangled a ray of hope, or may be false hope, for Egyptians. The hope propaganda was and has been utilized to present a promising future to the Egyptian people if they will only make the right choice and be eager proponents, as the media is, to the men of 
action in the military. While performing such a persuasive function, the media tends to violate the five principles of the TARES test. The first principle of the test, Truthfulness, is violated since it requires the message to appeal to the need of the recipient to have truthful information to inform his life decisions. This is also one of the demands of the Respect principle, as it demands the persuasive message to facilitate the recipient capacity to reflect and make responsible decisions (i.e. choose speak, vote or purchase well). The Respect principle also requires the message to take into account the well being of others. It also violates the authenticity principle since the motive should not be to manipulate others for a specific purpose. Considering the persons and circumstances involved, it also violates the principle of Equity, because on the one hand, the power of persuasion is targeted towards a vulnerable audience, sick and poor people. While on the other, it makes claims outside of their ability to understand the context and underlying claims of communication. The Social Responsibility principle is also violated since the potential negative impact on individuals and the common good is not taken into account.

\section{The Presentation of $U s$ and Them}

General Abdel Atti, among many other Egyptian journalists, presenters and politicians, tends to label anyone suspicious of the invention as irrational through the process of "othering." This can be related to Van Dijk's (1998) ideological square and the process of positive selfrepresentation and negative other-representation as explained below.

In response to the announcement of the invention, Dr. Essam Heggy, a planetary scientist in the Radar group at NASA propulsion laboratory and the scientific advisor of the president, states in Al-Wattan Newspaper that the invention is a scientific scandal for Egypt. Dr. Heggy's declaration gets harsh criticism from General Abdel Atti who announces, in AlWafd Newspaper, that the effectiveness of the device will be enough to disprove skepticism. He also declares, in Al-Omma Newspaper, that he stands as a "pyramid" while others, including intelligence forces around the world and Dr. Heggy, are just "cockroaches" (“Headline-General”, 2014)..

Moreover, TV presenters tend to defend General Abdel Atti who, in an attempt to prove that he is completely above suspicion, said in a phone interview with Mustafa Bakri of Sada AlBalad, that he is one of a kind and a descendant of the Islamic Prophet Mohammad. This 
signaled the end of discussion for him. Mostafa Bakri also claims that Heggi is taking revenge because he could not join the army as he was not mentally and physically fit to serve. He also claims, on Sada Al-Balad TV, that when he asked General Al-Sisi about the efficiency of the invention, the General almost cried out of happiness. However, as a guest on Al-Hayat TV, Albakri claims that General Taher Abdulla informed him that when El-Sisi saw the invention he was shaking and almost cried out of happiness. Amani Al-Khayat of ON TV demands President Adli Mansour to "deal with his advisors". While Naela Omara of AlKahera Wal Nasasserts the President that "he does not need a scientific advisor" and wonders if NASA has become a "disabled federation" since Dr. Heggy is one of the members. Twfeeq Okasha of Al-Fareen wonders who Essam Heggy is and suspects his patriotism since he is the “comer from France” (“The Program, Season 3, Episode 6”, 2014).

Hamedden Sabahi, the candidate for the Egyptian presidency, has also been a subject to much criticism since he is running against Elsisi, who has been called lately, by some Egyptian presenters, as Egypt's president-in-waiting. Sabahi is accused by Ahmad Mosa of Al-Tahrir of stealing the thunder of the military and taking credit for inventing the device, by attributing it to the Egyptian Popular Current, his political party. He explicitly labels the armed forces men as men with "more action and less talk", while the members of the Egyptian Popular Current are labeled as "big mouth-no action" people. He also explains that the perceived features of both sides are the cause of their superior/inferior position (“Ahmad Mosa", 2014).

All the examples above show how the media attempts to influence the public perception of politicians and interpretation of campaigns in order to direct the voters' decision making. The media coverage involves both a categorization and an evaluation of the "other" that is in the most cases stereotyped as inferior. It also casts issues to emphasize the concept of "otherness" and stress the boundaries between Us and Them, in order to convey the message of 'you are either with us or against us". Additionally, it violates the Respect principle of the TARES test since it represents a form of self-promotion at the unfair expense of others. Moreover, it violates the principle of Equity since it does allow neither reflection nor counterarguments which naturally are expected to arise. 


\section{Lack of Evidence}

Dr. Heggy is not the only one questioning the efficiency of the invention. Dr. Islam Hussain, a research scientist of Massachusetts Institute of Technology, questions the capacity of both C-Fast and CCD to detect and cure the virus in a detailed presentation posted on YouTube. He shows how both inventions lack scientific evidence and even "resemble electromagnetic projectile devices that appear in science fiction"(“C-Fast”, 2014). Moreover, Professor of Liver Surgery at Mansora University, Dr. Mohammad Abdel Whahed, stresses, in a phone call to al-Fareen TV, the need for announcing such inventions by a reliable expert who can scientifically inform the public about the interpretation and implications of the invention(“Tawfeeq Okasha”, 2014). However, and as reported by Al-Sharq TV, General Abdel Atti used to appear on the famous Islamist Satellite TV station Al-Nas, which was closed after the second revolution for inciting hatred and violence, as a doctor of alternative medicine. Moreover, he was not a military man but has been awarded an honorary military title ("Exclusive, Al-Sharq", 2014).

After all, Dr. Abdel Atti has not yet provided any scientifically plausible evidence on how the proposed device functions, how its safety was confirmed, which scientific committees reviewed and approved it, and what pre-post treatment tests were conducted to prove the efficiency of the device and on what treatment/control groups...etc. He rather violates the scientific norms of reporting by the unique language he uses: "Kofteh, cockroaches...etc". This violates the principle of Truthfulness, of the TARES test, since it lacks relevant evidence. The Respect principle is also violated since it requires the message to appeal to the recipient higher inclination by not exploiting or appealing to his lower inclinations. Consequently, we can say that the media has conducted a propaganda campaign that exaggerates the importance of the device and magnifies the role of the military in building a brighter future.

However, faced with harsh criticism, the media has started changing its tone on the invention and calling for evidence, especially after Dr Adel Adawy, the Minister of Health and Population, announced that Egypt has finalized an agreement with U.S. based Gilead to reduce the cost for Gilead's hepatitis C drug, Sovaldi, for $\$ 300$ a month, for a one-month box, which is equivalent to 2200 Egyptian pounds. He also added that the treatment will start in the second half of 2014, the date for when the army announced their device will be 
available, following completion of registration procedures in Egypt (Fick \& Hirscler, 2014).In the meantime, General Abdel Atti and his team still hold on to their claims that the device will be available by June for all Egyptians and this raises the question whether Egyptians will get a Sovaldi-based treatment or will be "cured" by the Complete Cure Device! In his article "Egypt Miracle Hepatitis, HIV Cure Farce Continues", Abdel-Raheem (2014) sheds light on the conflicting news on the efficiency of the device. He also criticizes the media and government's spread of false hope and misleading promises since health is seen as a patriotic issue, and for many Egyptians health security is a more serious problem than military security. For him, lying to the people about their health is a terroristic act that 'kills' both the body and soul.

Finally, the analysis above shows that the power of media resides in its ability to function as a propaganda system that serves the ideological agenda of a certain party. Iggers (1999:5) explains that:

This cynicism of journalists is rooted in the profound contradiction between the stated mission of the press, which is to provide citizens with the information they need to play an active role in democratic life, and the reality of daily practice, which systematically compromises values of public service in favor of other interests. (Iggers, 1999, p.5)

According to Herman and Chomsky's (1988) Propaganda Model, such systematic biases can be filtered with reference to Ownership, Funding, Sourcing, Flak, Anti-communisms (which is updated to refer to the war on terror) in order to investigate the embedded biases, motivations, and power relations within a particular context. Further studies may be conducted to shed light on media ownership, government sourcing and other aspects to further assess the ethicality of the media coverage of the Complete Cure Device.

\section{Conclusion}

This paper examines the ethicality of the media's promotion of Marshal el-Sisi as a presidency candidate for Egypt. The promotion of the military regime is often approached through several political and electoral actions, in addition to the media role that is investigated in this paper. If the political and electoral actions are said to work on legitimacy, then political media can be seen as playing a complementary and supportive role by assuring 
publicity. However, seeking effectiveness may conflict with rules of ethical conduct. Here, media institutions have to choose in terms of prioritizing professionalism over effectiveness or vice versa. Addressing the Political Media; pursuing effectiveness might force to neutralize accountability, professionalism and ethics aside. Usually, this is more pronounced in the main stream media, as privately controlled networks are not expected to produce government propaganda automatically. However, and as the study shows, in the Egyptian case the establishment policy of media organizations became a key driver to overlook professionalism and ethics in the Media of miracles, obfuscation, and demonization of the other. Through the use of critical discourse analysis and the application of the TARES test to the media coverage of the release of the army-invented device, the study concludes that that TV channels understudy are not slipping out of the government control. They are rather spreading the government's hope propaganda in an attempt to rule out any civilian opposition to military rule, that has supposedly come to an end after the transition process; enshrine the political independence of the army; legitimize the authoritarian military rule; and promote a more democratic and nationalist ideology of the military regime. This leads to the questions of how real the transfer of power from military to civilians after the transition process was, how often and under what circumstances the military will feel obliged to intervene, and how military-civilian relations will shape Egypt's future. 


\section{References}

Abdel Raheem, A, (2014, March 14). Egypt Miracle Hepatitis, HIV Cure Farce Continues. The Commentator. Retrieved from http://www.thecommentator.com/

Ahmad Mosa:Hamdeen Sabahi hawal yasroq ekhtera' alqwwat al mosalaha [ Hamedden Sabahi Tried to Steal the Invention of the Military Forces] [Video file]. (2014, February 23). Retrieved fromhttp://www.youtube.com/watch?v=xLCpCzvcOXY Al-barnameg-mawsesem 3- alhalqa 6 kamelah [The Program, Season 3, Episode 6][Video file]. (2014, March 14). Retrieved from http://www.youtube.com/watch?v=s601NqJPRTM

Al-barnameg-mawsesem 3- alhalqa 4 kamelah [The Program, Season 3, Episode 4][Video file]. (2014, February 28). Retrieved from http://www.youtube.com/watch?v=kpDL6u9Zo8

Baker, S., \& Martinson, D. (2001). The TARES Test: Five Principles for Ethical Persuasion. Journal of Mass Media Ethics, 16(2\&3), 148-175.

DOI:10.1080/08900523.2001.9679610

Black, J., \& Roberts, C. (2011). Doing ethics in media theories and practical applications. New York: Routledge.

Black, J. (2001). The Ethics of Propaganda and the Propaganda of Ethics. In L. Wilkins \& C. G. Christians (Eds.), The Handbook of Mass Media Ethics (pp. 130-148). New York: Routledge.

Capurro, R., \& Britz, J. (2010). In search of a Code of Global Information Ethics: The Road Travelled and New Horizons. The International Journal of Communication Ethics, 7(2/3), 28-36.

C-Fast \& Complete Cure, Scientific Question Marks [Video file]. (2014, February 28).

Retrieved from https://www.youtube.com/watch?v=ZDvInUrUrDs

Chakravartty, p., \& Sarikakis, K. (2006). Media Policy and Globalization. Edinburgh: Edinburgh University Press.

Cooper, N. (1966). Some Presuppositions of Moral Judgments. Mind, New Series, 75(297), 45-57 Retrieved from http://www.jstor.org/stable/2251709

Cunningham, S. (1992). Sorting out the Ethics of Propaganda. Communication Studies, 43(4), 233-245. Retrieved from http://academic.evergreen.edu/

Egyptian Army Claims Miracle Cure for Hepatitis C and HIV [Video file]. (2014, February26). Retrieved from http://www.youtube.com/watch?v=2plhq-VqDbI 
Egyptian Army Medical Research: AIDS in a Kebab Skewer [Video file]. (2014, February 25). Retrieved from https://www.youtube.com/watch?v=O1fdHT5PfcA

Egypt's Military Medics Claim to Have HIV/Aids Cure [Video file]. (2014, February 24).

Retrieved from http://www.youtube.com/watch?v=rVq8xbmq_j8

Ellul, J. (1981). The Ethics of Propaganda. Communication, 6(2), 159-175. Retrieved from http://ellul.org/ELLUL\%20FORUM\%20ARTICLES/ISSUE37.pdf

Fairclough, N. (2003). Analyzing Discourse: Textual Analysis for Social Research. London and New York: Routledge.

FICK, M., \& HIRSCHLER, B. (2014, March 21). Gilead Offers Egypt New Hepatitis C Drug at 99 pct Discount. Reuters. Retrieved from http://www.reuters.com

Flower, R. (1991).Language and News: Discourse and Ideology in the Press. London and New York: Routledge.

Hammodeh, R. (2014, March 24). Hal yosbeh ekhtera' al-kofta 'enwanan lenaksat yonyo okhra [Will the Kofta Invention Signal a New Naksa? ]. The New People Newspaper. Retrieved from http://elshaab.org/thread.php?ID=103988

Hasryan-taqrer qanat al-sharq 'an lewa' soba' al-kofta [Exclusive, Al-Sharq TV Report on General Kofteh] [Video file]. (2014, February 27). Retrieved from http://www.youtube.com/watch?v=4b1TdbyNwKY

Herman, D., \& Chomsky, N. (1988). Manufacturing Consent the Political Economy of Mass Media. New York: Pantheon Books.

Iggers, J. (1999). Good News, Bad News: Journalism Ethics and the Public Interest. Boulder, Colo.: Westview Press.

Kellner, D. (2005). The Media and Election 2004. Critical Studies in Media Communication, 22(2), 178-186. DOI: 10.1080/07393180500093794

Lange, B. P., \& Ward, D. (2004). The Media and Elections: A Handbook and Comparative Study. London: Lawrence Erlbaum Associates, Publishers.

Marlin, R. (2005). Some Problems in Jacques Ellul's Treatment of Propaganda. TroudeChastenet, 283-294 Retrieved from

http://ellul.org/ELLUL\%20FORUM\%20ARTICLES/ISSUE37.pdf

Manshet-algeneral kofta: ana al-haram wast al-saraser [Headline - General "kofta": I am the Pyramid among Cockroaches] [Video file]. (2014, March 2). Retrieved from http://www.youtube.com/watch?v=PbJYejdm0C4

Mosco, V. (2004). The Digital Sublime: Power and Cyberspace. Cambridge, 
MA: MIT Press.

Prakash, G. (1999). Another Reason: Science and Imagination in Modern India.

Princeton: Princeton University Press.

Salim, M. (2014, February 23). A Conference to Announce the AIDS and Hepatitis Curing Device. Al-Ahram. Retrieved from http://gate.ahram.org.eg/

Sadmet Tawfeeq Oqasha ba'da ma 'arafa haqeqat ekhtera' a;gayesh bta' al-vayrosat [Tawfeeq Okasha's Shock after Finding out the Truth of the Invention] [Video file]. (2014, February 25). Retrieved from http://www.youtube.com/watch?v=O-ZvVcWggLs Sanders, K. (2003). Ethics \& journalism. London: Sage.

Saleh, M. (2013 October 25). Is Egypt heading to "Ikhanization", "Wafdanization" or "Militarization"?. MEMO Middle East Monitor. Retrieved from https://www.middleeastmonitor.com

Van Dijk, T.A. (1996). Discourse Opinions and Ideologies. In C. Schaffner and H. Kelly Holmes (Eds), Discourse and Ideologies, (pp. 7-37). Clevedon: Multinqual Matters LTD.

Waters, K., \& Melton, J. (2006, August). The TARES Test as an Ethical Analysis Tool: Assessing the Ethicality of Direct Response Television Programs. Paper presented at the Association for Education in Journalism and Mass Communication, San Francisco.

Willems, W. (2012). The Ballot Vote as Embedded Ritual: A Radical Critique of LiberalDemocratic Approaches to Media and Elections in Africa. African Studies, 71(1), 91107. DOI: $10.1080 / 00020184.2012 .668295$

Wolfsfeld, G. (1997). Media and Political Conflict: News from the Middle East. Cambridge: CUP 


\section{Appendix}

\section{Reflection and Application Tables of the TARES Test}

\section{Table 1}

\section{Truthfulness (of the Message)}

Is this communication factually accurate and true, and also truthful? Does it deceive others either overtly or covertly? Does it lead people to believe what I myself do not believe? (Bok, 1989, p. 13)

Is this communication consistent with open, sincere, and honest communication? Is it responsive to the persuadees' human need to have truthful information to inform their life decisions?

Would I feel that this communication was truthful and nondeceptive if communicated to me in this context?

Is this communication substantially complete? Does it satisfy a reasonable person's requirements for information in this situation? (Klaidman \& Beauchamp, 1987, p. 35)

Have comparisons between alternatives been presented in an undistorted and truthful manner? (Cooper \& Kelleher, 2000)

Has this appeal downplayed relevant evidence? (Cooper \& Kelleher, 2000)

If this message communicates only part of the truth, what are my justifications for disseminating this selective (incomplete) truth? Are my omissions meant to deceive? (Deaver, 1990, pp. 168-177)

Am I creating a false image or a false impression with selective information? Will the people receiving this message feel they have been deceived if later they learn the whole truth? Is the information withheld needed by the audience for their own choices and actions? Will not having this information result in any harm? (Fitzpatrick \& Gauthier, 2000) Will people have reason to question my honesty and trustworthiness as a result of this communication?

What can I do to ensure that this persuasive message is truthful? 


\section{Table 2}

\section{Authenticity (of the Persuader)}

Does this action compromise my integrity? Does it conform to my highest principles? Is it true to my best self? Does it conform to my religious convictions?

Does this action arise out of noble intentions and motivations? (Cunningham, 2000.) Although I may have the right to do this, is it the right thing to do?

Do I personally believe in this product, company, service, event, idea, cause? Can I support and advocate it wholeheartedly and in person, including to people I know and love?

Would I openly, publically and personally be an advocate for this cause? Or am I hiding behind the anonymity of a promotional campaign or the work of others?

What is the rule or maxim on which I am acting? Is this rule justifiable? Would I want others to follow the same rule in similar circumstances?

Would I ideally want to live in a world in which people routinely engaged in this type of action? If not, what is my justification for engaging in it myself?

What good reasons and justifications do I have for advocating this product, service, or cause (other than purely self-serving reasons)?

By engaging in this action, am I cooperating with evil or encouraging or requiring others to do so? (Martinson, 1999, pp. 120-122.)

Do I feel good about being involved in this action? How will I feel if others find out about my participation? Am I willing to take full, open, public, and personal responsibility for this action? (Waltz, 1999, pp. 127-128.)

Do I truly think and believe that the persuadees will benefit (or will be doing the right thing) if they are persuaded to act or think in the ways that this persuasive communication suggests they should?

Is the motive of my action or communication (or of the secret I am keeping) to hurt, deceive, manipulate, or use others merely for my own or my client's purposes (to the detriment and at the expense of the persuadees)?

Does this action properly and appropriately (without hurting others) balance my loyalties in this situation to self and conscience, employer, society, humanity, clients, supporters, stockholders, profession and professional colleagues, family, friends, and others who have treated me well? Have I pursued a moral ideal with integrity, despite the behavior of others in society or with whom I work? Am I taking appropriate responsibility for the moral conduct of the organizations with which I work? (Raper, 1999, pp. 123-125.) 
What can I do to conduct myself as an authentic person in this situation?

\section{Table 3}

\section{Respect (for the Persuadee)}

Is the persuasive appeal made to the decency in people? Have I respected the receivers of this persuasive message by appealing to their higher inclinations and their basic goodness, by not pandering, exploiting, or appealing to their lower or baser inclinations?

Does this action or communication respect the persuadee as a human being worthy of dignity and respect? Have I taken the rights, interests, and well-being of others into consideration as much as my own?

Is the persuasive appeal made to persuadees as rational, self-determining beings? Does it facilitate persuadees' capacity to reflect and to make responsible choices about their lives? Does this action conform to my own religious convictions, and to religious perspectives that people should act with a spirit of caretaking and loving kindness toward others (Christians, Fackler, \& Rotzoll, 1995, p. 19).

What ethical responsibility do I have for the people I am targeting with this persuasion?

What can I do to be more respectful of and more responsible to the people I am persuading, and all others who will be affected by this persuasion?

Is the quality of this information adequate to the information needs of the persuadees? Does this persuasive message facilitate the persuadees' capacity to act well (i.e., to choose, speak, vote, or purchase well)? (Cunningham, 2000)

Will the persuadees benefit (will they be doing the right thing for themselves and others) if they are persuaded to act or think in the ways that this communication suggests they should? Does this action promote raw self-interest at the unfair expense of or to the detriment of persuadees?

Does this persuasive appeal contribute to understanding, consideration, reflection, and valid reasoning, and facilitate informed, free-will assent and consent? (Cunningham, 2000)

\section{Table 4}

\section{Equity (of the Persuasive Appeal)}

Is the context, nature and execution of this persuasive act fair? Is the power of persuasion used fairly and justly?

Is there parity in this situation between the persuader and persuadee in terms of information, 
understanding, insight, capacity, and experience? If not, have accommodations been made to adjust equitably for the disparities and to level the playing field?

Would I feel that the persuasion in this situation was fair, just, ethical and appropriate if it were communicated to me or to people I know and love? Am I doing to others what I would not want done to me or to people I care about?

Is this a persuasion that should not be made, considering the persons and circumstances involved?

Have I unfairly targeted specific (or vulnerable) audiences and made claims outside of their ability to understand the context and underlying claims of the communication? (Patterson \& Wilkins, 1998, p. 63.)

Do persuadees understand what I am claiming my product/service/ company/ position is and can do? Are they able to assess these claims fully and rationally? Do they thoroughly understand the costs and potential harms to themselves and others of what I am advocating? Is this persuasive appeal sensitive to the needs, interests, concerns, and sensibilities of the persuadees? (Cooper and Kelleher, 2000.)

Does it allow for both reflection and counterargument? (Wilkins and Christians, 2000.)

Do the receivers of the message know that they are being persuaded rather than informed?

Has this persuasion taken unfair advantage of a power differential? (Gauthier, 2000)

What can I do to make this persuasive appeal more fair and equitable?

\section{Table 5}

\section{Social Responsibility (for the Common Good)}

Does this action recognize the interdependency of persons in society, of persons as communal beings? (Christians et. al., 1995, p. 332) Is the action/ communication responsible to individuals, society, the public, and the public interest?

Will the product or issue I am promoting cause harm to individuals or to society? Does this action conform to the ethical requirement to do no unnecessary harm or to prevent harm?

Does this action take responsibility to promote and create the kind of world and society in which persuaders themselves would like to live with their families and loved ones? (Baker, 1999)

Have I legitimately and fairly participated in the marketplace of ideas such that competing ideas fairly can be heard and considered by the public? Have I considered the responsibility to fairly represent issues and to allow and foster public consideration of alternative views? 
(Moyers, 1999)

Has this action's potential negative impact on individuals and the common good been taken into account and responded to appropriately?

Does this persuasive communication promote (or strain) understanding and cooperation among constituent groups of society? Does it enhance or deplete public trust? (Bok, 1989, p. 26)

Will this action (or not having this information) cause disproportionate harm to any person, group, or interest? (Fitzpatrick \& Gauthier, 2000)

Have I taken seriously the challenge of defining how I can positively serve the interests and views of the traditionally underrepresented in society? (Martinson, 1998, p. 148) Have I unfairly stereotyped constituent groups of society in this promotion/ communication campaign?

Does this persuasive communication elucidate issues, dispel confusion and ignorance, and encourage public dialogue based on truthful information? (Cunningham, 2000) 